\title{
INDEMNITY UNDER WORKERS' COMPENSATION: RECOGNIZING A SPECIAL LEGAL RELATIONSHIP BETWEEN MANUFACTURER AND EMPLOYER
}

As Professor Arthur Larson once noted, in one of the inost often quoted observations on the subject of workers' compensation, "[p]erhaps the most evenly-balanced controversy in all of compensation law is the question whether a third party in an action by the employee can get contribution or indemnity froin the employer, when the employer's neghgence has caused or contributed to the [employee's] mjury."1 Both state and federal workers' compensation acts contain exclusive-remedy provisions that limit an employer's hability to the payment of workers' compensation benefits; ${ }^{2}$ the question, however, is to what extent these imitations affect a third party's traditional rights of contribution or indemnity from other neghigent parties.

Workers' compensation creates an equation that roughly balances the sacrifices by and benefits to both employers and employees. Employees receive faster and virtually certain recovery, while sacrificing their claims against employers; employers assume a new hability, while being relieved of large dannage verdicts. ${ }^{3}$ This balance, however, fails to ac-

1. 2A A. LaRson, The LAwS OF WORKMEN's COMPENSATION $\$ 76.11$, at 14-561 (1987).

2. Three types of "exclusive liability" clauses are generally found in workers' compensation legislation:

(a) The "Massachusetts Type, which only says that the employee, by coming within the act, waives his common law rights." This type is the most narrow and the least common.

(b) The "California and Michigan Type, which says that the employer's liability shall be "exclusive,' or that he shall have "no other liability whatsoever." "

(c) The New York Type, which specifies "that the excluded actions include those by "such employee, his personal representatives, husband, parents, dependents or next of kin, or anyone otherwise entitled to recover damages, at common law or otherwise on account of injury or death." "The types listed at (b) and (c) are the most common.

See id. $\S \S 66.10-66.22$ (quoting CAL. LAB. CODE $\S 3601$ (West 1966); Mich. CoMP. LAws $\$ 411.4$ (1968); N.Y. WORK. COMP. LAW $\S 11$ (McKinney 1968)). Decisions concerning recovery of third parties usually have not turned on the language of the statutes. See United States Fidelity \& Guar. Co. v. Kaiser Gypsum Co., 273 Or. 162, 167 n.2, 539 P.2d 1065, 1067 n.2 (1975).

3. 2A A. LARSON, supra note $1, \S 65.11$, at $12-9$. 
count for the rights and interests of third parties such as manufacturers. ${ }^{4}$ Many state workers' compensation acts explicitly state that the right of an employee to bring an action agamst a third party is not removed by the act. 5 If an employee takes advantage of this right to sue third parties, and the third party then tries to assert its own claim for contribution or indemnity agamst a neghigent employer, the third party often finds the exclusive-remedy provision an insurmountable hurdle. ${ }^{6}$ Legislatures have not included third-party interests as a variable when formulating workers' compensation schemes. Consequently, unlike employees, third parties receive no benefits im exchange for the sacrifice of their claims against employers. ${ }^{7}$

It is not surprising-in light of the mequitable statutory treatment of third-party claims - that courts often struggle with the workers' compensation equation im an attempt to balance the interests of all parties on the scales of justice and at the same time remain faithful to legislative intent. Authorities are divided as to whetlier a given state's exclusiveremedy provision operates as an absolute bar to all claims against employers ${ }^{8}$ or merely governs rights between employers and their employees. In the latter case, third parties are free to pursue independent

4. See generally Carlson v. Smogard, 298 Minn. 362, 368, 215 N.w.2d 615, 619 (1974) (workmen's compensation act intended only to control rights between employer and employee (quoting Lunderberg v. Bierman, 241 Minn. 349, 364, 63 N.W.2d 355, 365 (1954))); Weisgall, Product Liability in the Workplace: The Effect of Workers' Compensation on the Rights and Liabilities of Third Parties, 1977 Wis. L. Rev. 1035, 1081 (arguing that manufacturers should be made part of workers' compensation system); Comment, The Effect of Workers' Compensation Laws on the Right of a Third Party Liable to an Injured Employee to Recover Contribution or Indemnity from the Employer, 9 SETON HALL L. REv. 238, 241 (1978) ("[W]orkers' compensation law governs the employer's liability to the employee [while] general tort law governs the third party's liability to the employee.").

5. For example, in New Jersey:

Where a third person is liable to the employee or his dependents for an injury or death, the existence of a right of compensation from the employer or insurance carrier under this statute shall not operate as a bar to the action of the einployee or his dependents, nor be regarded as establishing a measure of damage therein.

N.J. STAT. ANN. § 34:15-40 (West 1987).

6. See infra note 8 and accompanying text. The third party may assert its claim for indemnity either before or after adjudication of the employee's claim against it.

7. Lunderberg v. Bierman, 241 Minn. 349, 363, 63 N.W.2d 355, 365 (1954) (third party gains nothing from workers' compensation scheme); 2 A A. LARSON, supra note $1, \S 76.11$, at 14563 (third party a stranger to compensation system).

8. Alabama is the only state that holds that its workers' compensation act bars any and all claims by third parties against employers due to injured employees' recovery froin third parties. See Paul Krebs \& Assoc. v. Matthews \& Fritts Constr. Co., 356 So. 2d 638, 640 (Ala. 1978) (workers' compensation statute proteets employer from suit by third party seeking indemnity from employer under contractual provisions). A federal court interpreting Tennessee law has inade a sinilar interpretation of the Tennessee workers' compensation act. See Tennessee River Pulp \& Paper Co. v. Eichleay Corp., 708 F.2d 1055, 1058 (6th Cir. 1983) (affirming denial of third-party indemnity action due to previous broad interpretations of the exclusive-remedy provision of Tennessee workers' compensation act). 
claims. A third party's right to contribution or indemnity must be addressed in this context. 9

The inequities of strict apphication of the workers' compensation exclusive-remedy provision have multiphed with the developinent of products hability theory. A manufacturer is now held strictly hable for a

Several other states, including Nevada and Oregon, have statutes that, in addition to the exclusive-remedy provision, bar all third-party claims against an employer under workers' compensation. See Nev. REv. Stat. ANN. \$ 616.265 (Michie 1986); OR. REv. STAT. \$ 656.018 (1987). Other states, such as California, Pennsylvania and Texas, have statutes that allow recovery only when there is a specific written agreement to that effeet between a manufacturer and an employer. See CAL. LAB. Code $\S 3864$ (West 1971); PA. Stat. ANN. tit. 77, § 481(b) (Purdon Supp. 1987); TEX. Rev. Crv. STAT. ANN. art. 8306, \& 3(d) (Vernon Supp. 1988). See generally 2A A. LARSON, supra note 1, $\S \S 76.44-76.45$ (listing state statutes that provide no right of recovery against employer by a third person in absence of written agreement).

9. A majority of state high courts as well as the United States Supreme Court have held that state and federal workers' compensation acts were intended to govern only the rights of employees, their relatives and people claiming through them or on behalf of them. See, e.g., Lockheed Aircraft Corp. v. Umited States, 460 U.S. 190, 199 (1983) ("FECA's exclusive-liability provision does not directly bar a third-party indemnity action against the United States." (citation omitted)); Oaklawn Jockey Club, Inc. v. Pickens-Bond Constr. Co., 251 Ark. 1100, 1101-02, 477 S.W.2d 477, 478 (1972) (Workers' compensation does not abolish third party's right to implied imdemnity.); Arcidiacono v. Wilmington Fimishing Co., No. 84C-AU-86 (Del. Super. Ct. Sept. 10, 1986) (LEXIS, States library, Del file) ("Delaware law clearly recognized contractual claims of indemnity against an employer by third parties as an exeeption to the [workers' compensation] exclusivity principle."), cert. denied, 516 A.2d 482 (Del. 1986); Houdaille Indus., Inc. v. Edwards, 374 So. 2d 490, 492 (Fla. 1979) (mitially valid indemnity claim proper in spite of workers' compensation); Hirasha v. Burtner, 702 P.2d 772, 774 (Haw. 1985) (indemnity allowed if based on contract or other independent duty to imdemmify); Burgdorff v. International Business Machs., 35 Ill. App. 3d 192, 194, 341 N.E.2d 122, 124-25 (1975) (to invoke implied indemnity, must show either a preexisting relationship between the parties or a qualitative difference between the two parties' negligence); Iowa Power \& Light Co. v. Abild Constr. Co., 259 Iowa 314, 322-23, 144 N.W.2d 303, 308 (1966) (indemtrity permitted for express contracts, vicarious liability or breach of an independent duty running from employer to third party); Union Carbide Corp. v. Sweco, Inc., 610 S.W.2d 932, 934 (Ky. Ct. App. 1980) (imdemnity claims under workers' compensation may be maintained); Decker v. Black \& Deeker Mfg. Co., 389 Mass. 35, 38, 449 N.E.2d 641,643 (1983) (question of right to indemnity under workers' conpensation based on implied contract left undecided); Grayson v. Chambersburg Eng'g Co., 139 Mich. App. 456, 460-61, 362 N.W.2d 751, 754 (1984) (implied contract of indemnity recognized); Lambertson v. Cincinnati Corp., 312 Minn. 114, 127, 257 N.W.2d 679, 687-88 (1977) (might allow indemtrity if third party not at fault; contribution allowed); Ramos v. Browning Ferris Indus., 103 N.J. 177, 188-89, 510 A.2d 1152,1158 (1986) (indemnity allowed when special relationship exists between employer and third party, and latter is only vicariously liable); Dole v. Dow Chem. Co., 30 N.Y.2d 143, 152-53, 282 N.E.2d 288, 294, 331 N.Y.S.2d 382, 390 (1972) (indemnity allowed based on independent legal duty); Harter Concrete Prods., Inc. v. Harris, 592 P.2d 526, 528 (Okla. 1979) (indemnity allowed if independent relationship exists between employer and third party); Boldman v. Mt. Hood Chem. Corp., 288 Or. 121, 129, 602 P.2d 1072, 1076 (1979) (indemnity allowed if special legal relationship exists); Olch v. Pacific Press \& Shear Co., 19 Wash. App. 89, 93, 573 P.2d 1355, 1357 (1978) (Indemmity is permitted (1) if there is a breach of an independent duty between an employer and a third party, (2) if there is vicarious liability, or (3) because of the passive negligence of a third party as conpared to active negligence of an employer.); Sydenstricker v. Unipunch Prods., Inc., 169 w. Va. 440, 446, 288 S.E.2d 511, 515 (1982) (implied indemnity allowed, but only when third party without fault). See generally 2A A. LARSON, supra note 1, supp. at 190-92 (Dec. 1987) (citing more recent cases for $\S 76.81$, at $14-734$ n.22). 
defective product put into the flow of commerce; ${ }^{10}$ when a manufacturer of machinery discovers a defect in its product, it imcurs a nondelegable duty both to cure the defect and to warn users of the defect's existence. ${ }^{11}$ Occasionally, however, an employer will decline a manufacturer's offer to install a curative device even after being fully informed of the machine's defect, ${ }^{12}$ and an employee of this neghigent owner will mjure himself on the defective machine in precisely the manner anticipated by the manufacturer. The injured employee automatically receives workers' compensation benefits from the employer, and the exclusive-remedy provision extinguishes all other claims against the employer resulting from that particular injury. ${ }^{13}$ The injured einployee may, however, proceed against the manufacturer with a products hability claim alleging that the original defect was the proximate cause of the imjury, and despite its good-faith efforts to cure, the inanufacturer may still be found hable to

10. According to the Restatement (Second) of Torts:

(1) One who sells any product in a defective condition unreasonably dangerous to the user or consumer ... is subject to liability for physical harm thereby caused to the ultimate user or consuiner. ...

(2) The rule stated in Subsection (1) applies although

(a) the seller has exercised all possible care in the preparation and sale of his product, and

(b) the user or consumer has not bought the product from or entered into any contractual relationship with the seller.

RESTATEMENT (SECOND) OF TORTS $\$ 402 \mathrm{~A}$ (1965). A product is defective when it is in a condition not contemplated by the user that is unreasonably dangerous. Id. $\S 402 \mathrm{~A}$ comment g; see also Dorsey v. Yoder Co., 331 F. Supp. 753, 758 (E.D. Pa. 1971) (Inanufacturer hable if product unreasonably dangerous); Greenınan v. Yuba Power Prods., 59 Cal. 2d 57, 62, 377 P.2d 897, 900, 27 Cal. Rptr. 697,700 (1963) (manufacturer strictly liable for injuries resulting from defective article placed on the market). A danger is unreasonable when it is foreseeable. See Foster v. Ford Motor Co., 616 F.2d 1304, 1308-11 (5th Cir. 1980); Balido \%. linproved Mach., 29 Cal. App. 3d 633, 640, 105 Cal. Rptr. 890,895 (1972).

11. See, e.g., Borel v. Fibreboard Paper Prods. Corp., 493 F.2d 1076, 1089 (5th Cir. 1973) (manufacturer has duty to warn of latent nonobvious dangers and of defects in products); Stephenson v. R.A. Jones \& Co., 103 N.J. 194, 216, 510 A.2d 1161, 1172 (1986) (If a defect is discovered after a sale, a manufacturer has a duty either to remedy the defect or to give users adequate warnings.).

12. See Mitchell, Products Liability, Workmen's Compensation and the Industrial Accident, 14 DuQ. L. REv. 349, 375-76 (1976) (employers may remain unpersuaded as to inerits of design defect correction). Possible reasons for the employer's refusal nnay include the undesirability of halting production-even temporarily-while the safety device is installed, the knowledge that the safety device inay decrease the inachine's productivity, the general attitude that the device is a "hassle" that need not be contended with, or the fecting that the device is unnecessary because no injury has yet occurred. Cf. Derosa v. Remington Arms Co., 509 F. Supp. 762, 764, 769 (E.D.N.Y. 1981) (employer abused product to suit his awn needs); Noonan v. Spring Creek Forest Prods., 700 P.2d 623, 624 (Mont. 1985) (employer told plaintiff not to turn off defective planer because it would slow down production); Duk Hwan Chung v. Fred Meyer, 1nc., 276 Or. 809, 811, 556 P.2d 683, 684 (1970) (dead-man switch, a safety device, replaeed by standard switch when employee complained).

13. 2A A. LARSON, supra note $1, \S 65.31$, at $12-21$ (employer relieved of all other liability if injury covered by workers' compensation); see also supra note 2 and accompanying text. 
that einployee for the injury. ${ }^{14}$ The manufacturer, in turn, might pursue a claim for contribution or indemnity against the uncooperative employer, arguing that "but for" the actions of the employer the accident would never have occurred. ${ }^{15}$ Unfortunately, mecharical apphication of the exclusive-remedy provision of workers' compensation results in dismissal of the manufacturer's claim. This result could be extended to absurd lengths: an employer, under some statutory scheines, might be entitled to reimburseinent from a manufacturer for any workers' compensation payments, ${ }^{16}$ creating the possibility that an employer could escape all hability even though he prevented any correction of faulty machinery.

Although dismissing the inanufacturer's claim im such a situation may seem bizarre, it was the result im the recently decided Stephenson $v$. $R . A$. Jones \& Co. ${ }^{17}$ In Stephenson, a manufacturer had sent letters to all owners of its machines informing them of a discovered defect and asking them to install the safety device that was being forwarded to them at no cost. The manufacturer shipped some of these safety devices to the particular employer, but the employer never installed the devices. The safety device cost $\$ 300$ (which the manufacturer absorbed) and took less than thirty mimutes of minimal labor to install. ${ }^{18}$ Five years later, while inspecting the employer's plant, the manufacturer discovered that the curative safety devices had never been installed. The manufacturer renewed efforts to cure the employer's defective machines. Four letters and two offers to send new devices were ignored. An injury then occurred. The injured worker successfully sought damages from the manufacturer. The manufacturer then sought indemnity from the employer assertimg that the employer frustrated attempts to cure the machinery once the defect was discovered.

The dissenting opinion in the New Jersey Supreine Court argued that the issue of the employer's lack of cooperation should have been

14. The manufacturer may be found liable on the basis of a jury determination that the employer's refusal to have the curative device installed was a "foreseeable consequence" of placing the defective machine into a flow of commerce and therefore does not relieve the manufacturer of liability. See infra notes $26-44$ and accompanying text. Additionally, the court might direct a verdict against the manufacturer. See, e.g., Stephenson v. R.A. Jones \& Co., 103 N.J. 194, 218 n.17, 510 A.2d 1161, 1173 n.17 (1986) (Stein, J., dissenting).

15. W. Prosser, D. Dobbs, R. Keeton \& D. OWen, Prosser and Keeton on The Law OF TORTS $\$ 41$, at 266 (5tli ed. 1984) [hereinafter PROSSER \& KEETON].

16. See Mitchell, supra note 12, at 362 n.42, 370 (right of subrogation for negligent employer under debate); Weisgall, supra note 4, at 1046-49 (absolute subrogation for employer regardless of fault "inconsistent" with principles of subrogation and negligence). See generally 2A A. LARSON, supra note 1 , and $\$ \S 71.20,74.10-74.15$ (avoiding double rccovery; mechanics of subrogation).

17. 103 N.J. 194, 510 A.2d 1161 (1986).

18. Id. at 202, 510 A.2d at 1165 (Stein, J., dissenting). 
submitted to the jury; if the jury found the employer frustrated a legitimate attempt by the manufacturer to cure the defective product, the indemnity claim should bie. ${ }^{19}$ The majority, however, disagreed, holding that because the jury found the manufacturer to be five percent at fault, the claim for indeninity could not override the exclusive-remedy provision of the workers' compensation act and the manufacturer's claim was dismissed. ${ }^{20}$

This note first examines the rationale of allowing a jury to decide the question of hability when a manufacturer is prevented from curing machime defects by the negligent or reckless conduct of an employer. ${ }^{21}$ Next, the note addresses manufacturers' alternatives of contribution or indemmity against such uncooperative employers. ${ }^{22}$ The note argues that in these situations manufacturers have legitimate claims for indemnity from employers due to the breach of an independent duty running from the employer to the manufacturer to allow the manufacturer to cure machine defects. ${ }^{23}$ This duty is based on comnion law tort principles and is supported by public pohicy. ${ }^{24}$ The note concludes that allowing indemnity for the breach of an employer's duty to a manufacturer is neither barred by workers' conipensation acts nor judicially contrived to undermine such acts, but rather promotes an overall legislative scheme of safety in the workplace. ${ }^{25}$

\section{Manufacturers' Liability as a Question of FORESIEEABILITY FOR THE JURY}

A manufacturer will be held strictly hable for putting into commerce a machine that creates an unreasonable risk of harm to its user. ${ }^{26}$ The injured user need only show that the machine was defective when it left the manufacturer's control and that this defect caused the injury sustained. ${ }^{27}$ Likewise, a manufacturer has a duty to cure any subsequently discovered defects in its machines because failure to correct such defects

19. Id. at 218, 510 A.2d at 1173 (Stein, J., dissenting). Whether the einployer did in fact frustrate attempts to cure was unclear, but the majority decided that this issue did not create a jury question. Id. at 199-200, 510 A.2d at 1163-64.

20. Id, at 199,510 A.2d at 1163 . The idea that indemnity is only available to a party held hable through no personal fault is addressed infra notes 133-41 and accompanying text.

21. See infra notes $26-44$ and accompanying text.

22. See infra notes $45-145$ and accompanying text.

23. See infra notes $82-145$ and accompanying text.

24. See infra notes 90-123 and accompanying text.

25. See infra notes $124-45$ and accompanying text.

26. See supra note 10 and accompanying text.

27. See, e.g., Gracyalny v. Westinghouse Elec. Corp., 723 F.2d 1311, 1317 (7th Cir. 1983). 
also subjects a user to an unreasonable risk of harm. ${ }^{28}$

An exception to this general rule exists if a manufacturer can show that, in any particular situation, its conduct was not the proximate cause of the user's injuries. ${ }^{29}$ The manufacturer would argue that it took all reasonable steps to cure the discovered defect and that the employer's refusal to implement or install the corrective measures or devices was the actual cause of the injury. A manufacturer thwarted in its curative steps by an employer could argue that the duty of the manufacturer to the employee/user was interrupted by the neghigent (or willful) conduct of the employer. In other words, the einployer's actions became the superseding and intervening cause of the injury. These actions break the causal chain between the product and the injury and reheve a manufacturer of liability. ${ }^{30}$

Despite the logic of such an argument, it is often unsuccessful in a jury trial. ${ }^{31}$ As a matter of law, only those intervening causes that are not foreseeable consequences of a manufacturer's breach of duty to an employee/user will absolve the manufacturer of hability. ${ }^{32}$ As the finder of fact, the jury is usually asked in these cases to determine whether the manufacturer could reasonably foresee that an employer would resist at-

28. See, e.g., La Belle v. McCauley Indus. Corp., 649 F.2d 46, 49 (1st Cir. 1981) (manufacturer held hable for failure to warn of need to modify airplane propeller when need discovered after sale); Braniff Airways, Inc. v. Curtiss-Wright Corp., 411 F.2d 451, 453 (2d Cir.) (manufacturer held liable if defects not remedied or adequate warnings not given), cert. denied, 396 U.S. 959 (1969).

29. Proximate cause is both a cause in fact of the injury (a factor which contributed to the injury) and the legal cause of the injury (the factor for which the courts will inpose liability). ProsSER \& KEETON, supra note $15, \S 42$, at 272-73.

30. Gracyalny v. Westinghouse Elec. Corp., 723 F.2d 1311, 1322 (7th Cir. 1983) ("Superseding cause [is] an act by a third person ... which by its intervention prevents a negligent person from being held liable for harm to another."); Mitchell, supra note 12, at 369 (same). The Restatement (Second) of Torts states:

The fact that an intervening act of a third person is negligent in itself ... does not make it a superseding cause of harm to another...., if

(a) the [original negligent] actor at the time of his negligent conduct should have realized

that a third person might so act, or

(b) a reasonable man ... would not regard it as highly extraordinary that the third person had so acted.

RESTATEMENT (SECOND) OF TORTS $§ 447$ (1965).

31. See Mitchell, supra note 12, at 370 (jury may overlook technicalities of causation in order to compensate an employee deserving sympathy); $c f$. Self v. General Motors Corp., $42 \mathrm{Cal}$. App. 3d 1, 8-9, 116 Cal. Rptr. 575, 578 (1974) (jury-when presented with substantial credible evidence from both sides-ruled against the manufacturer and for the consumer in defective design case); Duke v. Gulf \& Western Mfg. Co., 660 S.W.2d 404, 414 (Mo. Ct. App. 1983) (affirming jury verdict in favor of employee and against manufacturer in products liability case although conflicting evidence on question of foreseeability).

32. See, e.g., Toth v. Yoder Co., 749 F.2d 1190, 1196-97 (6th Cir. 1984) (intervening negligence of third party does not relieve manufacturer of liability unless the third party's acts or oinissions are unforeseeable); Gracyalny v. Westinghouse Elec. Corp., 723 F.2d 1311, 1323 (7th Cir. 1983) (same); Mitchell, supra note 12, at 369 (same). 
tempts to cure the machine once a defect was discovered. ${ }^{33}$ If the jury finds that the employer's noncooperation was a foreseeable consequence of putting a defective machine into the fiow of commerce, the employer's conduct does not cut off the manufacturer's hability to the employee. ${ }^{34}$ At the same time, the employer is immune from any tort suit brought by the employee, and in the event that the employee recovers from the manufacturer, the employer could even be reimbursed for any workers' compensation payments made. ${ }^{35}$

The possibility of allowing the question to be decided as a matter of law has appealed to some courts. ${ }^{36}$ A closer look at workers' compensation, however, reveals that under its present structure, the foreseeability question must be left to the jury. If an employer's refusal to take curative measures is ruled, as a matter of law, to be a superseding and mtervening cause of an employee's injuries, then the manufacturer is relieved of liability and the employee must look to the employer for compensation. Exclusive-remedy provisions, however, bar any recovery by an employee that exceeds the workers' compensation payinents. ${ }^{37}$ This present structure, therefore, would assume a policy decision that employees should bear most of the loss when originally defective products go uncured due to the employers' noncooperation. This result not only offends any sense of justice, it also is contrary to both the traditional products hability scheme of allocating $\operatorname{cost}^{38}$ and the traditional idea that one who is at

33. See, e.g., Rhea v. Massey-Ferguson, Inc., 767 F.2d 266, 269 (6th Cir. 1985) (determinations of proximate cause and foreseeable risk present jury questions); Toth, 749 F.2d at 1196 (whether employer's modification of machine constitutes superseding cause is jury question); Gracyalny, 723 F.2d at 1323 (foreseeability of enployer's acts is a jury question); Herman v. Welland Chem., Ltd., 580 F. Supp. 823, 828 (M.D. Pa. 1984) (superseding cause presents questions that are normally for jury); Balido v. Improved Mach., Inc., 29 Cal. App. 3d 633, 645, 105 Cal. Rptr. 890, 899 (1972) (extent to which manufacturers are required to anticipate safety neglect presents issue of fact). But see infra note 36 and accompanying text.

34. See, e.g., Toth, 749 F.2d at 1197 (jury found manufacturer negligent because modifications in design made by plaintiff's employer were "foreseeable"); Ford Motor Co. v. Matthews, 291 So. $2 \mathrm{~d}$ 169, 177 (Miss. 1974) (affirming judge's finding of manufacturer's liability despite negligent omission of dealer in failing to heed manufacturer's warning); cf. DeRosa v. Remington Arms Co., Inc., 509 F. Supp. 762, 768-70 (E.D.N.Y. 1981) (jury verdiet finding manufacturer of handgun liable for production of defective firearm overturned because fellow officer's misnse of the firearm was not foreseeable as matter of law).

35. See Mitchell, supra note 12, at 370; see also supra note 7 and accompanying text.

36. See, e.g., Meuller v. Jeffrey Mfg. Co., 494 F. Supp. 275, 277, 279 (E.D. Pa. 1980) (proximate cause normally jury question but when there is no factual dispute, court properly should rule on issue; finding employer's conduct superseding cause); Rekab, Inc. v. Frank Hrubetz \& Co., 261 Md. 141, 274 A.2d 107 (1971) (manufacturer's warning and attempts to cure insulated him from liability as matter of law); Ford Motor Co. v. Wagoner, 183 Tenn. 392, 404, 192 S.W.2d 840, 845 (1946) (whether ignoring of offered remedy by intermediate owner constituted a superseding cause was decided by the court).

37. 2A A. LARSON, supra note $1, \S 65.11$, at $12-1$.

38. Prosser states the idea of risk-bearing allocation: 
fault should bear the cost of injury. ${ }^{39}$

Leaving the determination of foreseeability to the jury places the question of responsibility where it belongs-between manufacturers who create defective machines and einployers whose noncooperation prevents such machines from being corrected. This scheme also prevents innocent employees from bearing the cost of injury. Once found liable, ${ }^{40}$ a manufacturer should not be precluded from receiving reimbursement from the employer ${ }^{41}$ if the employer was truly noncooperative. ${ }^{42}$ Such reimbursement comports with the idea that one who is at fault should bear the cost. ${ }^{43}$ While the stymied manufacturer should be able to collect from the employer, in the event that the claim fails ${ }^{44}$ or the employer is insolvent, the ultimate risk of hability should fall on the manufacturer instead of the employee. Such a result would parallel the policy behind products hability.

\section{MANUfacturers' POSSIBILITY OF RECOVERY FROM EMPLOYERS WHO THWART EFFORTS TO CURE}

Once a manufacturer is frustrated im efforts to cure and is held hable for the employee's injury resultimg from the uncured defect, the manufacturer should be able to proceed against the einployer who thwarted the curative atteinpts. Under theoretical principles of tort law, the manufacturer has two options: contribution ${ }^{45}$ or indemnity. ${ }^{46}$ In practice, however, the exclusive-remedy provisions in inost state workers' coinpensation acts foreclose the contribution option and leave indemnity as the only viable alternative.

The costs of damaging events due to defectively dangerous products can best be borne by the enterprisers who make and sell these products. Those who are merchants and especially those engaged in the manufacturing enterprise have the capacity to distribute the losses of the few among the many who purchase the product[] . . . by charging higher prices for the costs of products.

Prosser \& Keeton, supra note $15, \S 98$, at $692-93$ (footnote omitted).

39. See, e.g., Bullock v. Black \& Decker, Inc., 502 F. Supp. 580, 583 (E.D. Mich. 1980) ("principle ... of restitution, requir[es] that everyone be responsible for his own negligence").

40. Most juries find against the manufacturer in these cases. See supra note 34 and accompanying text.

41. See infra notes $82-145$ and accompanying text.

42. 2A A. LARSON, supra note $1, \S 71.10$, at $14-1$ ("[E]very mature loss-adjusting mechanism ... must make the injured person whole, and it must . . . seek out the true wrongdoer whenever possible.").

43. See infra notes $38-39$ and accompanying text.

44. Such a claim should fail, for instance, where the employer's actions may not have been so reprehensible or where the manufacturer's attempts to cure may not have been so persistent. See, e.g., Ford Motor Co. v. Matthews, 291 So. 2d 169, 177 (Miss. 1974) (manufacturer sent out ouly one written warning-ignoring it not reprehensible).

45. See infra notes 47-59 and accompanying text.

46. See infra notes $60-93$ and accompanying text. 


\section{A. Contribution.}

Contribution is a statutory or common law remedy that allows damages among joint tortfeasors to be apportioned according to the degree of fault of each tortfeasor. ${ }^{47}$ For a claim of contribution, both parties must be jointly liable in tort so that a common liability is imposed upon thein. ${ }^{48}$ This coinmon law requirenent is codified in the Uniform Contribution Among Tortfeasors Act, which defines joint tortfeasors as "two or inore persons [who] becoine jointly or severally hable in tort." 49

At first glance, it would seem that both a manufacturer who places a defective machine in the market and an employer who refuses to allow the defect to be corrected contribute proportionately to an employee's injuries. In such a case, contribution would be the appropriate remedy for a manufacturer. Under contribution, a manufacturer would collect an ainount equal to an einployer's proportion of fault. ${ }^{50}$ Workers' compensation, however, extinguishes all tort hability of employers to their employees. ${ }^{51}$ Einployers' hability is statutory while manufacturers' liability is tort-based. ${ }^{52}$ Because an employer is not "jointly or severally" liable in tort with a inanufacturer and because their acts do not form a common liability, an employer is not considered a joint tortfeasor. Therefore, an einployer is not open to a claim of contribution..$^{53}$

Altliough this result may seem harsh and counterintuitive, ${ }^{54}$ most

47. Lambertson v. Cincinnati Corp., 312 Minn. 114, 128, 257 N.W. 2d 679, 688 (1977); ProsSER \& KEETON, supra note $15, \S 51$, at 341.

48. See, e.g., American Dist. Tel. Co. v. Kittleson, 179 F.2d 946, 951 (8th Cir. 1950); Hendrickson v. Minnesota Power \& Light Co., 258 Minn. 368, 371, 104 N.W.2d 843, 847 (1960).

49. UNif. Contribution AMONG TORTFEAsors ACT § 1(a), 12 U.L.A. 63 (1955).

50. See supra note 47 and accompanying text.

51. See supra note 13 and accompanying text; see also Kittleson, 179 F.2d at 951 ("Because of the [compensation] Act [the employee] has no common law action in tort against [the employer] as a result of his injuries ....").

52. See Kittleson, 179 F.2d at 951 (employee's right to rccover from employer based on compensation act while right to recover from manufacturer based on tort law; therefore "no common source of liability" existed between entployer and manufacturer); Speck v. Umit Handling Div., Litton Sys., 366 N.W.2d 543, 548 (Iowa 1985) (denial of contribution based on lack of common liability between third party and employer); ses also Larson, Third-Party Action Over Against Workers' Compensation Employer, 1982 DUKE L.J. 483, 488 ("The claim of the employee against the employer is solely for statutory benefits; his claim against the third person is for damages.").

53. Larson, supra note 52 , at 488 .

54. See, e.g., Stephenson v. R.A. Jones \& Co., 103 N.J. 194, 199, 510 A.2d 1161, 1163 (1986) ("legislative scheme may seem liarsh"). In fact, several state courts have attempted to alleviate "tlie sometimes liarsh effects of the employer's immninty." See id. at 205-07, 510 A.2d at 1166-67 (Stein, J., dissenting) (citing Larson, supra note 52, at 491-500). These attempts, as listed in Stephenson, include:

[T] he former "Pennsylvania Rule" (contribution by employer permissible because contribution between joint tortfeasors depends on joint negligence rather than joint liability); the Minnesota Rule ... (contribution by employer permitted in proportion to fault but not in excess of workers' compensation liability); the California and North Carolina approach 
courts have been reluctant to disregard the legislative intent to extinguish employers' tort hability toward their employees. 55 Unless an employer can be said to be originally hable to an injured employee, contribution is not available. ${ }^{56}$ Although employer immunity from contribution has generated much criticism, ${ }^{57}$ and has caused various commentators to propose comparative fault systems, ${ }^{58}$ the language of the statutes is clear. ${ }^{59}$ Until the statutory language of exclusive-remedy provisions is changed, contribution is not a possible remedy.

\section{B. Indemnity.}

Indemnity is the common law reinedy that shifts the loss from the one who has been forced to pay it to another who should bear it imstead. ${ }^{60}$ In other words, the one most at fault should be the one to pay. ${ }^{61}$

\footnotetext{
(where employer's negligence contributed to the injury, the employee's third-party recovery is reduced by the amount of the compensation awarded); the "Murray Credit" rule (employee's judgment against third party tortfeasor should be reduced by einployer's pro rata share after employee's recovery against employer under workers' compensation act); the New York rule ... (employer required to indemnify third-party tortfeasor based on einployer's degree of fault in causing employee's injury); and the Illinois rule ... (employer hable for contribution based on degree of fault and amount of contribution not limited by employer's obligation under worker's compensation law).
}

Id. at 205-06, 510 A.2d at 1167 (Stem, J., dissenting) (footnotes omitted).

55. Many courts and commentators have criticized the contribution remedy in this situation because " allowance of such recovery over accomplishes indirectly what cannot be done directly and, therefore, evades the spirit of the legislation.' "Lambertson v. Cincinnati Corp., 312 Minn. 114, 129, 257 N.W.2d 679, 688 (1977) (quoting Larson, Workmen's Compensation: Third Party's Action Over Against Employer, 65 Nw. U.L. REv. 351,419 (1970)); see also Stephenson, 103 N.J. at 206-07, 510 A.2d at 1167 (Stein, J., dissenting) (noting same criticism); cf. Rupe v. Durbin Durco, Inc., 557 S.W.2d 742, 750 (Tenn. Ct. App. 1976) (naking same criticism of indemnity claims). For an extensive list of cases disallowing contribution, see $2 \mathrm{~A}$ A. LARson, supra note $1, \S 76.20$. See also Prather v. Upjohn Co., 585 F. Supp. 112, 113-14 (N.D. Fla. 1984) (Manufacturer has no right of contribution against third party because the parties cannot be jointly or severally liable as required by Florida statute.); Ramos v. Browning Ferris Indus., 103 N.J. 177, 183-85, 510 A.2d 1152, 115556 (1986) ("The New Jersey Rule is consistent with that of the great majority of jurisdictions, which hold that the [workmen's compensation] precludes a elaim for contribution against an employer ....").

56. Prosser \& KeEton, supra note $15, \S 50$, at $339-40$.

57. See, e.g., Lambertson, 312 Minn. at 119-30, 257 N.W.2d at 684-89; Davis, Third-Party Tortfeasors' Rights Where Compensation-Covered Employers Are Negligent-Where Do Dole and Sunspan Lead?, 74 HoFsTRA L. REv. 571 (1976); Mitchell, supra note 12, at 364-65, 395-97; Weisgall, supra note 4, at 1049-50; Comment, Contribution and Indemnity in California, 57 CALIF. L. REv. 490, 516 (1969); Comnent, supra note 4, at 298-99.

58. See, e.g., Davis, supra note 57, at 580-83; Mitchell, supra note 12, at 395-97; Comment, supra note 4 , at 300-03.

59. 2A A. LARSON, supra note $1, \S 76.20$, at 14594 ("The claim of the employee against the einployer is solely for statutory benefits ...." (emphasis added)).

60. W. Prosser, LAW OF TORTS $\S 51$ (4th ed. 1971).

61. Cf. Stephenson v. R.A. Jones \& Co., 103 N.J. 194, 208, 510 A.2d 1161, 1168 (1986) (Stem, J., dissenting). This definition becomes important later. See infra notes 138-41 and accompanying text. 
Most courts recognize third-party contractual indemnity claims against negligent employers who participate in workers' compensation if the indemnity agreement is unambiguously expressed in the contract. ${ }^{62}$ Even in the absence of an express agreement, many courts allow soine form of a third-party indemnity claim under workers' compensation. ${ }^{63}$

Implied indemnity can rest on one of two concepts. The first concept allows indemnity under the comnion law principle that when one party is conipelled to pay for another's wrong, the party without fault should be able to recover froin the party whose neghigence caused the injury. ${ }^{64}$ This concept allows indemnification of employers under workers' conipensation in some jurisdictions when a third party is either vicariously liable 65 for another's neghigence, or when a third party's conduct "passively" contributes to an mjury while the employer's action "actively" causes the injury. ${ }^{66}$

The second concept of indemnification is based on the established principle that if a person breaches a duty owed to another and the breach causes injury, that person should compensate the one to whom the duty was owed. ${ }^{67}$ Under workers' compensation this duty would run from employers to manufacturers. In order to comport with the exclusiveremedy provisions, this duty would need to be independent of any potential liability of an employer toward an employee. In other words, the manufacturer/employer relationship must be found to exist separately froin an employer's relationship with an enployee. ${ }^{68}$ This second con-

62. See Larson, supra note 52 , at $500-01$ \& n.79.

63. See supra notes 8-9 and accompanying text.

64. See Stephenson, 103 N.J. at 208, 510 A.2d at 1168 (Stem, J., dissenting); Sydenstricker v. Unipunch Prods., Inc., 169 W. Va. 440, 445, 288 S.E.2d 511, 515 (1982).

65. Vicarious liability occurs when one party is held responsible for the acts of another due to some relationship existing between the parties. Prosser \& KeETON, supra note $15, \S 69$, at 499 .

66. Passive negligence is found in mere nonfeasance (as opposed to misfeasance), such as the failure to perform a duty imposed by law. It is contrasted with active negligence where the indemnitee has personally participated in an affirmative negligent act or an omission. See Rossmoor Sanitation, Inc. v. Pylon, Inc., 13 Cal. 3d 622, 629, 532 P.2d 97, 101, 119 Cal. Rptr. 449, 453 (1975). Passive/active negligence is also referred to as secondary/primary negligence. See Olch v. Pacific Press \& Shear Co., 19 Wash. App. 89, 93, 573 P.2d 1355, 1357 (1978).

67. See generally Prosser \& K.eEToN, supra note 15, § 53.

68. Roy v. Star Chopper Co., 442 F. Supp. 1010, 1018-19 (D.R.I. 1977) ("The implied obligation to indemnify mnst rest on a particular duty the employer ... owes to the manufacturer, distimct from the duty he owes to his employees."), aff'd, 584 F.2d 1124 (1st Cir. 1978), cert. denied, 440 U.S. 916 (1979); Bonus Bilt, Inc. v. United Grocers, Ltd., 136 Cal. App. 3d 429, 437, 186 Cal. Rptr. 357,361 (1982) (no justification for shielding employer from hability if injury arises from relationship distinct from employer's duties to employees); Stephenson, 103 N.J. at 207, 510 A.2d at 1167 (Stein, J., dissenting) (clash with employer immunity under workers' compensation less direct when duty is "extricable from the tortious conduct that caused the injury"); Mitchell, supra note 12, at 383 (compensation statutes do not bar claims by third party founded on an employer's duty to third party which is extraneous to employer/employce relationship). 
cept finds subtle application im the context of a manufacturer's claim against an uncooperative employer who is otherwise protected by workers' compensation. ${ }^{69}$

1. Vicarious Liability and Active/Passive Negligence. A manufacturer who has produced a defective machine cannot seek indemnity from a concurrently neghigent employer under a theory of vicarious hability when an employee is injured by the machine. The true basis of vicarious liability is largely a public or social policy determination that, irrespective of fault, the parties stand in such a relationship that one should be held to respond for the acts of another. ${ }^{70}$ Under the products hability sclieme, a manufacturer becomes liable for any mjury caused by placing a defective product on the market. The act of placing a defective machine into tlie flow of comnerce is independent of any subsequent conduct on the part of the employer. Thus, a manufacturer's hability is not based upon any alleged fault of an employer, ${ }^{71}$ and a manufacturer is not held to respond solely for the acts of another. ${ }^{72}$

Similar reasoming would preclude a manufacturer from recovering from an employer on a theory of active/passive negligence. A party may seek indemnity from another if there is a large disparity between the kind of negligence committed by the two parties and if the party's own fault was merely "passive" while the other party's fault was "active." "Active" negligence denotes some positive act or an omission that is the equivalent of a positive act. 73 "Passive" negligence denotes the failure to do something that should have been done. ${ }^{74} \mathrm{~A}$ manufacturer, under this theory, would argue that its neghigence in selling a defective machine was passive, while the negligence of the employer in refusing the safety device was the active negligence that caused the imjury. ${ }^{75}$ Once again, however, the nature of the manufacturer's liability prevents successful use of this argument. In a products liability action a manufacturer is held strictly

69. The recognition of a special legal relationshp was proposed by Judge Stein in his dissent in Stephenson, 103 N.J. at 207, 510 A.2d at 1167.

70. Nadeau v. Melin, 260 Minn. 369, 375-76, 110 N.W.2d 29, 34 (1961).

71. See, e.g., White v. Johns-Manville Corp., 662 F.2d 243, 249-50 (4th Cir. 1981) (In a products liability action under admiralty law, a manufacturer cannot characterize any resulting liability as secondary to any alleged fault of an employer.).

72. See, e.g., Adler's Quality Bakery, Inc. v. Gaseteria, Inc., 32 N.J. 55, 79, 159 A.2d 97, 109 (1960) (An owner of an aircraft is entitled to indemmity if he is free of fault and the liability of another merely imputed to him.).

73. 65 C.J.S. Negligence $\S 1(14)$ (1966).

74. Id.

75. For a general example of this kind of argument, see White, 662 F.2d at $246-47$. 
liable for an injury caused by an unreasonably dangerous product. ${ }^{76}$ Such liability is viewed as active hability because the manufacturer "actively" designed and marketed the product ${ }^{77}$ and cannot claim that it merely "passively" failed to discover a preexisting defect. ${ }^{78}$ In other words, for the purpose of indemnification, courts equate strict products liability with active neghigence. ${ }^{79}$ Therefore, indemnity would not be available to a manufacturer under an active/passive neghigence theory.

Even if indennification through an active/passive negligence theory were available to a inanufacturer, a court would first have to find the employer negligent toward the employee. This finding requires liability in tort. ${ }^{80}$ Workers' compensation statutes preclude finding an employer liable in tort to an employee. ${ }^{81}$ Therefore, theories of vicarious liability and active versus passive negligence have no application to a manufacturer seeking indeinnity from an employer who thwarted the manufacturer's curative attempts.

\section{Independent Dutj-Contractual or Special Legal Relationship.} Another claim for implied indemnity arises when one party owes a duty to another party and the breach of that duty is separable from the tortious conduct to the original plamtiff. ${ }^{82}$ This duty, either based in contract $^{83}$ or in tort, ${ }^{84}$ carries with it the obhigation to imdemnify. ${ }^{85}$ In those

76. See, e.g., Widson v. International Harvester Co., 153 Cal. App. 3d 45, 60, 200 Cal. Rptr. 136, 147 (1984) (quoting Dart Transp. Serv. v. Mack Trucks, Inc., 9 Cal. App. 3d 837, 849, 88 Cal. Rptr. 670, 678 (1970)).

77. See, e.g., White, 662 F.2d at 250 (failure to warn of defective product is active fault); Swindlehurst v. Resistance Welder Corp., 110 Mich. App. 693, 698, 313 N.W.2d 191, 194 (1981) (active fault of manufacturer exists in design and/or manufacture of machine).

78. Cf. Jackson v. Associated Dry Goods Corp., 13 N.Y.2d 112, 116-17, 192 N.E.2d 167, 170, 242 N.Y.S.2d 210, 214 (1963) (generally landlord only passively negligent when failing to discover and remedy dangerous condition afîrmatively created by another).

79. See, e.g., Iowa Power \& Light Co. v. Abild Constr. Co., 259 Iowa 314, 324-25, 144 N.W.2d 303,309 (1966) (manufacturer's failure to make product nondangerous is active and not passive negligence); Arcell v. Ashland Chem. Co., 152 N.J. Super. 471, 493, 378 A.2d 53, 64 (1977) ("If defendants are found liable in strict liability, it will be because of their conduct in [actively] manufacturing or distributing a defective product ....").

80. Slattery v. Marra Bros. Inc., 186 F.2d 134, 139 (2d Cir.) (When a worker under an employment contract surrendered rights to recovery except for workers' compensation, a tenant was not entitled to indemnity from a stevedore for damages the worker recovered from the tenant.), cert. denied, 341 U.S. 915 (1951); Iowa Power, 259 Iowa at 323, 144 N.W.2d at 309 (requirement of concurrent negligence bars indemmification claims under workers' compensation based on active/ passive negligence).

81. See supra note 51 and accompanying text.

82. See supra notes $67-68$ and accompanying text.

83. See, e.g., Arcidiacono v. Wilmington Finishing Co., No. 84C-AU-86 (Del. Super. Ct. Sept. 10, 1986) (LEXIS, States library, Del file), cert. denied, 516 A.2d 482 (Del. 1986). This contract may be expressed or implied but typically requires an employer to undertake some service or perform some act for a manufacturer. See 2A A. LARSON, supra note 1, § 76.72, at 14-716 to 14717. 
states that allow some kinds of imphied indemnity claims, manufacturers may maintain claims for indemnity despite the exclusive-remedy provision of workers' compensation. Because an employer's hability arises out of the breach of an independent duty owed to a manufacturer and not out of an employee's injury, the exclusive-remedy provision does not apply. ${ }^{86}$

A manufacturer does not enjoy a special relationship with the employer based solely on the contract of sale. A contrary rule would require the courts to imply a duty of employers to use the purchased product in such a way so as not to expose sellers to hability. ${ }^{87}$ Courts have consistently refused to imply a duty of care that "flows upstream from the purchaser [of a product] to the manufacturer," 88 because this holding would negate the very purpose of products hability law. ${ }^{89}$ Although other contracts between manufacturers and einployers may

Some courts confuse the boundaries between an implied contract and a special legal relationship. An implied contract should properly be viewed as one set of circumstances which gives rise to a special relationship (here contractual) and the implied promise to indemnify. Some courts, however, will recognize a special relationship between the parties only when it is contractual in nature, that is, when one party specifically undertakes to perform some act or service for the other party. Failure to separate the specific types of indemnity claims that inay legally exist has unnecessarily narrowed the field of recovery for manufacturers with legitimate claims against employers. See infra notes $133-45$ and accompanying text. For a good overview of the different kinds of indemnity claims available, see Stephenson v. R.A. Jones \& Co., 103 N.J. 194, 207-12, 510 A.2d 1161, 1167-70 (1986) (Stein, J., dissenting).

84. See, e.g., Stephenson, 103 N.J. at 207-08, 510 A.2d at 1168 (Stein, J., dissenting); Sydenstricker v. Unipunch Prods., Inc., 169 W. Va. 440, 445, 288 S.E.2d 511, 515 (1982) (quoting Hill v. Joseph T. Ryerson \& Son, Inc., 165 W. Va. 22, 27, 268 S.E.2d 296, 301 (1980)). This duty is sometimes expressed by courts as an "implied imdeinnity contract" betwecn the parties. See, e.g., Hill v. Sullivan Equip. Co., 86 Mich. App. 693, 697-98, 273 N.W.2d 527, 529 (1978).

85. Stephenson, 103 N.J. at 207-08, 510 A.2d at $1167-68$ (Stein, J., dissenting). This duty may also arise between the parties based on their legal relationship. Id. at 208-1 1, 510 A.2d at 1168-69 (discussing principal/agent, bailee/bailor, and employer/contractor relationships as examples).

86. See supra note 68 and accompanying text; see also Ryan Stevedoring Co. v. Pan-Atlantic S.S. Corp., 350 U.S. 124, 130 (1956) (noting shipowners' rights to rccover from indemnitor based on independent contractual right not related to employee's injury); Dole v. Dow Chem. Co., 30 N.Y.2d 143, 152, 282 N.E.2d 288, 294, 331 N.Y.S.2d 382, 390 (1972) (The plaintiff-inanufacturer suing the defendant-employer "asserts its own right of recovery for breach of an . . . independent duty . . . owed to it by the defendant." (quoting Westchester Lighting Co. v. Westchester Co. S.E. Corp., 278 N.Y. 175, 179, 15 N.E.2d 567, 568 (1938))).

87. See, e.g., Roy v. Star Chopper Co., 442 F. Supp. 1010, 1018-19 (D.R.I. 1977), aff'd, 584 F.2d 1124 (1st Cir. 1978), cert. denied, 440 U.S. 916 (1979); Arcell v. Ashland Chein. Co., 152 N.J. Super. 471, 490, 378 A.2d 53, 63 (1977); Olch v. Pacific Press \& Shear Co., 19 Wash. App. 89, 93-94, 573 P.2d 1355, 1357 (1978); 2A A. LARSON, supra note 1, $\$ 76.84$, at 14-751.

88. Decker v. Black \& Deeker Mfg. Co., 389 Mass. 35, 39, 449 N.E. 2d 641, 644 (1983) (quoting Williain H. Field Co. v. Nuroco Woodwork, Inc., 115 N.H. 632, 634, 348 A.2d 716, 718 (1975)).

89. For example, the Star Chopper court explained "[a]t first blush, we appear to be moving in a circle, imposing liability on the manufacturer on the one hand and excusing it on the other through the indemnity contract." 442 F. Supp. at 1021; see also Widson v. International Harvester Co., 153 Cal. App. 3d 45, 60-61, 200 Cal. Rptr. 136, 147 (1984) (implied indemnity against public policy of strict liability). 
create the special relationship that imposes the obligation to indemnify, such an obligation is not imposed on einployers througli a simple bill of sale.

The special relationship also may be imposed by law. Altlough sale of a machine, by itself, does not create a special legal relationship between a manufacturer and an employer, sucl a relationship is not precluded. Several courts have stated in dicta that under appropriate circumstances, an employer/manufacturer relationship will impose the obligation to indemnify. ${ }^{90}$ These courts recognize imdemnity as an equitable principle imposed by "law to prevent a result which is regarded as unjust or unsatisfactory." 11 Indemnity has been characterized as "a shifting of responsibility from the slioulders of one person to another; and the duty to indemnify has been recognized im cases where equities supported it." 92 Thus, the proper inquiry is whether the relationship between a manufacturer and an employer is sucli that the law should impose upon the employer some duty to the manufacturer to allow the manufacturer to cure defective products..$^{93}$

a. Imposing a "duty." The concept of a "duty" is merely a legal convenience. A "duty" is "a shorthand statement of a conclusion, ratler than an aid to analysis in itself" 94 and expresses those policy considerations that "lead the law to say that the plaintiff is entitled to protection."95 Once a "duty" is recognized as desirable, the courts simply work backward to find a special legal relationship between the two parties. ${ }^{96}$ If the circumstances warrant the recognition of a special relation-

90. Star Chopper, 442 F. Supp. at 1018-19; Gould v. General Mills, Inc., 411 F. Supp. 1181, 1184 (W.D.N.Y. 1976); see also Hill v. Sullivan Equip. Co., 86 Mich. App. 693, 698, 273 N.W.2d 527,529 (1978) (recognizing potential of special relationship between manufacturer and employer).

91. Prosser \& KeEton, supra note $15, \S 51$, at 341.

92. Id. § 51, at 344; cf. Dole v. Dow Chem. Co., 30 N.Y.2d 143, 153, 282 N.E.2d 288, 295, 331 N.Y.S.2d 382, 291-92 (1972) (right to apportionment or full indemnity should rest on relative responsibility and be determined by facts).

93. Stephenson v. R.A. Jones \& Co., 103 N.J. 194, 201, 510 A.2d 1161, 1170 (1986) (Stein, J., dissenting).

94. Prosser \& Keeton, supra note 15, § 54, at 358; cf. Earp v. Nobmann, 122 Cal. App. 3d 270, 290, 175 Cal. Rptr. 767, 778 (1981) ("[T] he concept of duty is simply a shorthand way of expressing whether the plaintiff's interests are entitled to protection against the defendant's conduct."); Brennen v. City of Eugene, 285 Or. 401, 406, 591 P.2d 719, 722 (1979) (same).

95. Prosser \& Keeton, supra note 15, §54, at 358; see also Green, The Duty Problem in Negligence Cases, 28 CoLUM. L. REv. 1014, 1023-26 (1928) (In imposing "duty," a court is deciding whether defendant must "bear the risk or whether plaintiff must bear his own loss."); Dumka v. Quaderer, 151 Mich. App. 68, 72, 390 N.W.2d 200, 202 (1986) ("[A] duty may be defined as an obligation, to which the law will give recognition and effect, to conform to a particular standard of conduct toward another." Existence of such a duty is a question of law.).

96. See infra note 98 and accompanying text. 
ship, they also warrant the recognition of the imposition of the duty. ${ }^{97}$ Thus, the concept of an independent duty and the concept of a special legal relationship merge. Both concepts describe the same result and are simply terms of art used to justify a social decision as to who should bear the loss in a given situation. ${ }^{98}$

To say that an employer has an independent duty to allow a manufacturer to cure a defect is to say, in effect, that in these situations a manufacturer's interests are entitled to legal protection against an employer's conduct. ${ }^{99}$ It is therefore necessary to look into the policy considerations for recognizing such a duty. When a manufacturer attempts to cure a defective product and an einployer frustrates these efforts, the employer is the one who should bear the cost of injury. The employer owes this obligation to the manufacturer because the manufacturer is otherwise unable to discharge its own duty to correct the defect.

Strong policy considerations support the imposition of an independent duty upon employers to allow the correction of defects by manufacturers. First, a duty to provide a safe product is imposed on manufacturers under products hability law. Manufacturers are responsible for the safety of their machines. ${ }^{100}$ This obligation naturally helps to maximize the safety of the workplace. ${ }^{101}$

97. Stephenson, 103 N.J. at 208-09, 510 A.2d at 1168 (Stein, J., dissenting) (special legal relationship gives rise to duty of indernnification); see also Leflar, Contribution and Indemnity Between Tortfeasors, 81 U. PA. L. REv. 130, 147 (1932) (relationship between parties "often affords the decisive clue" of what is fair); supra notes $90-93$ and accounpanying text.

98. See PrOSSER \& KEETON, supra note $15, \S 53$, at 357 (If "court should desire to find liability, it would be quite as easy to find the necessary 'relation' [between] . . . the parties . . . and hence to extend the defendant's duty to the plaintiff.").

99. Id. § 53, at 358. Professor Leon Green has articulated five factors which play a role in deciding whether a defendant owes a duty toward the plaintiff: (1) administrative (workability of the decision), (2) inoral, (3) economic, (4) preventative (ability of decision to control future conduct), and (5) considerations of "justice." Green, supra note 95 , at 1034.

Although each factor is not treated separately in this note, all the factors are satisfied in imposing a duty on an einployer to allow a manufacturer to cure defects. The imposition of the duty is limited and narrow, thus allowing workability. See infra notes 125-31 and accoinpanying text. Policy considerations discussed supra notes 108-23 and accompanying text support both unoral and justice considerations. Imposition of the duty would also have positive economic results as discussed supra notes 119-23 and accompanying text, and would also serve the function of preventing future harms. See infra note 122 and accoinpanying text; see also Prosser, Palsgraf Revisited, 52 Mrch. L. REv. 1, 15 (1953) ("There is a duty if the court says there is a duty" based on interplay of many factors.); $c f$. Moulton v. Groveton Papers Co., 112 N.H. 50, 52, 289 A.2d 68, 71 (1972) (liability imposed for breach of duty means defendant has departed from required standard of conduct).

100. See supra notes 10-11 and accompanying text.

101. Stephenson v. R.A. Jones \& Co., 103 N.J. 194, 216, 510 A.2d 1161, 1172 (1986) (Stein, J., dissenting) (central focus of products liability to minimize accidents); see also Bexiga v. Havir Mfg. Corp., 60 N.J. 402, 410, 290 A.2d 281, 285 (1972) (public interest in assuring that safety devices installed demands manufacturer be responsible for installation). 
Second, employers are under a similar duty imposed both by the common law and by statute to provide safe workplaces for employees. The common law duty requires employers to conform to a certain standard of conduct to use and maintain machines in a non-neghigent manner. ${ }^{102}$ Additionally, Congress and most state legislatures have enacted safety regulations requiring employers to furnish necessary protection devices for the safety of their einployees or to furnish a place of employment free from recognized hazards. ${ }^{103}$ This duty runs from employers to their employees and inclucles the duty of proper use and care of machines. ${ }^{104}$ In practice, however, these common law and statutory duties cannot adequately be enforced because workers' compensation relnoves liability for their breach. ${ }^{105}$ Although courts seem reluctant to recognize

102. Odom v. Monogram Indus., Inc., 555 F. Supp. 378, 379 (S.D. Tex. 1983).

103. Stephenson, 103 N.J. at 215, 510 A.2d at 1172 (Stein, J., dissenting). The dissent cited the Federal Occupational Safety and Health Act (OSHA), 29 U.S.C. § 651-78 (1982), which "exphicitly recognizes the national policy favoring a safe workplace." Stephenson, 103 N.J. at 215, 510 A.2d at 1172 (Stein, J., dissenting). Section 654 of the OSHA requires "that employers 'furnish to . . . employees ... a place of employment ... frec from recognized hazards....' includ[ing] a dangerous condition known to the employer." Id. (quoting 29 U.S.C. $§ 654$ (1982)).

Many states have similar safety statutes. E.g., CAL. LAB. CodE $\S 6403$ (West Supp. 1988) (Employers are charged with several duties including, "do[ing] every other thing reasonably necessary to protect the life, safety, and health of employees."); CONN. GEN. STAT. ANN. § 31-370(a) (West 1987) (Requiring that employers furnish "a place of einployment which [is] free froin recognized hazards that are causing or are likely to cause death or serious physical harm to [their] einployees."); N.J. STAT. ANN. § 34:6A-3 (West 1987) ("Every employer shall install, maintain and use such employee protective deviees and safeguards . . . as are reasonably necessary to protect the life, health and safety of employees . . ."); N.C. GEN. STAT. § 95-129 (1987) ("Each einployer shall furnish ... a plaee of employenent free from recognized hazards ....); TEX. REv. Civ. STAT. ANN. art. 5182(a) § 3 (Vernon 1987) ("Every employer shall furnish and maintain ... a place of employment which shall be reasonably safe and healthful for einployees.").

104. See, e.g., Roy v. Star Chopper Co., 442 F. Supp. 1010, 1018-19 (D.R.I. 1977) (einployer's duty of proper use and care of machine runs solely to its employees), aff'd, 584 F.2d 1124 (1st Cir. 1978), cert. denied, 440 U.S. 916 (1979) ; Duke v. Gulf \& Western Mfg. Co., 660 S.W.2d 404, 416 (Mo. Ct. App. 1983) (breach of einployer's duty inposed by safety statute is no defense to manufacturer; instead it means only both parties failed to adequately safeguard inachine); Mitchell, supra note 12, at 376 (willful failure to install safety device is breach of employer's obligation to einployee).

105. See Mitchell, supra note 12, at 376 . Because employers have no statutory or coininon law liability under workers' compensation, these safety regulations do not subject employers to such liability. Instead, if the regulations are violated, they operate to increase the workers' compensation award by a certain percentage, up to $100 \%$. As Mitchell points out, however, this extra payment is still quite inadequate as compensation to the einployee and is far less than he would receive if workers' compensation were not in operation.

Mitchell has suggested that federal and state safety regulatious could forn the basis of the independent duty between the enployer and the inanufacturer. The employer would owe a duty to the manufacturer not to violate any of these laws. The einployer would be fully liable to the manufacturer for a breach of a safety regulation which caused an increase in liability to the inanufacturer. Therefore, such a duty would supply the needed meehanism for ineaningful enforccinent of these regulations. Mitchell, supra note 12, at 384; see also General Elec. Co. v. Moretz, 270 F.2d 780, 78789 (4th Cir. 1959), cert. denied, 361 U.S. 964 (1960); Burris v. American Chicle Co., 120 F.2d 218, 222 (2d Cir. 1941). 
a duty running from employers to manufacturers based on safety regulations, ${ }^{106}$ the policies behind these regulations manifest a strong public interest in a safe workplace. ${ }^{107}$

Workers' compensation was not enacted to remove all incentive from employers to prevent employee injury. An employer may not willfully or intentionally injure an employee. ${ }^{108}$ In sucli instances, an employee is able to file a complaimt against lier employer despite the operation of workers' compensation. Filing an action is allowed because an injury of this type is said to liave lost its accidental cliaracter. ${ }^{109}$ Willfully subjecting an employee to dangerous work conditions miglit be considered an intentional tort that would entitle an employee to extra recovery. ${ }^{110}$ Thus, when an employer intentionally committed the act whicli injures an employee, that employer cannot allege the mjury was accidental and is covered by workers' compensation. ${ }^{11}$ Such an argument would seem to lave equal force when an employer intentionally prevents a manufacturer from correcting an unsafe inachine. The majority of courts, lowever, require a direct imtent to inflict injury; negligent or reckless conduct does not allow einployees directly to recover full dam-

106. Courts that have had to confront this issue have held that state and federal safety statutes were created for the benefit of the employee and thus create no cognizable relationship between the manufacturer and employer. See supra note 104 and accompanying text.

Denying third-party recovery based on safety statutes is unpersuasive. Courts could find that although the statutes were created for the benefit of the employee, their existence nonetheless imposes a duty on the employer not to violate them in ways that would injure third parties. See Mitchell, supra note 12, at 384; cf. Garrett v. Holiday Inns, Inc., 58 N.Y.2d 253, 258-64, 447 N.E.2d $717,719-23,460$ N.Y.S.2d 774, 776-80 (1983) (rejecting implied indemnification but finding town proportionately liable to hotel based on town's breach of safety regulations which caused damage to third parties).

107. See supra note 103 and accompanying text. These regnlations recognize either explicitly or implicitly that at least some responsibility for a safe workplace properly belongs to employers. See, e.g., Occupational Safety and Health Act of 1970, 29 U.S.C. § 651(b)(2) (1982) ("[E]mployers and employees have separate but dependent responsibihities and rights with respect to achieving safe and healthful working conditions ....."); CAL. LAB. CODE $\S 6423$ (West Supp. 1988) (penalties set out for employers who violate safety regulations); CONN. GEN. STAT. ANN. $\$ 31-382$ (West 1987) (same).

108. Davis v. Rockwell Int'l Corp., 596 F. Supp. 780,784 (N.D. Ohio 1984) (Workers' compensation does not preclude common law remedies for intentional torts by an employer.); Note, Exceptions to the Exclusive Remedy Requirements of Workers' Compensation Statutes, 96 HARV. L. REv. 1641,1650 (1983) (Many "courts find it unacceptable to immunize employers from bearing full tort damages for intentional injuries.").

109. Mandolidis v. Elkins Indus., Inc., 161 W. Va. 695, 705, 246 S.E.2d 907, 914 (1978); 2 A A. LARSON, supra note $1, \S 68.00$, at 13-1.

110. Mitchell, supra note 12, at 355-56 (penalty statutes provide for substantial increase in workers' compensation benefits or for suit at common law to recover for entire injury upon proof of willful amsconduct or injury by employer); Note, supra note 108, at 1650-51 (Tort action is permitted as an alternative to workers' compensation remedy for intentional imjury by employers.).

111. 2A A. LARSON, supra note $1, \S 68.11$, at $13-2,13-3 \mathrm{n} .1$ (citing cases explaining that workers' compensation covers only "accidental" injuries). 
ages from employers. ${ }^{12}$ Nonetheless, allowing recoveries for the intentional misfeasance of employers supports the idea that employers have a certain responsibility to maintain safety in the workplace, a responsibility for which they may be held accountable. ${ }^{113}$

Considering the duties of safety placed separately on both employers and manufacturers, the full implementation of legislative policies concerning safety in the workplace dictates that a duty between employers and inanufacturers also be recognized. ${ }^{114}$ Both inanufacturers and employers are committed to maintaining a safe work environment, ${ }^{115}$ but neitlier can fully perform their duties without the cooperation of the other. ${ }^{116}$ The law should not force manufacturers to wait helplessly for injury to occur-imjury for: which a inanufacturer may be held responsible. If the law imposes a duty on manufacturers to perform certain obhgations, it should also recognize the manufacturers' right to do that which the law requires. It: would be counterproductive to impose strict liability on manufacturers to maximize safety in the workplace and yet allow employers, who are also responsible for safety in the workplace, to forestall manufacturers' efforts to cure. ${ }^{117}$ Likewise, it is paradoxical to create safety regulations for employers and not to enforce them in any meaningful way. ${ }^{118}$

Placing the duty on employers to cooperate witl manufacturers not only upholds legislative intent but also furtleers the public imterest in a safe workplace. Besides the obvious desire to foster safe and productive work environments, the public would realize an economic benefit. Products liability is a judicial policy decision to place the cost of imjury on the manufacturer, who passes this cost indirectly to the public through the prices charged for goods. Risk of injury becomes part of the cost of do-

112. Id. §68.13, at 13-8 to 13-9; see Hildebrandt v. Whirlpool Corp., 364 N.w.2d 394, 396-97 (Minn. 1985).

113. Some courts have allowed recovery when the intent to injure has been indirect, but these instances are rare. See, e.g., Mandolidis, $161 \mathrm{~W}$. Va. at 706, 246 S.E.2d at 914. This area of workers' compensation shows that courts have had trouble balancing legislative intent with obvious misfeasance of employers.

114. These policies include allowing employees to sue manufacturers for products liability under workers' compensation acts and enacting safety statutes to make employers responsible for safe workplaces. See supra notes 5, 103-04 and accompanying text.

115. The manufacturer is committed through $\S 402 \mathrm{~A}$ Strict Product Liability, see supra note 10 and accompanying text, and the employer through the OSHA and state safety statutes, see supra note 103 and aecompanying text.

116. An employer must naturally rely on manufacturer's cxpertise and judgment when purchasing machines. A manufacturer, in turn, requires minimal cooperation from an employer $m$ order to inspect machines and to correct any defeets he subsequently may discover. The manufacturer is, of course, responsible for all associated costs, including downtime.

117. Stephenson, 103 N.J. at 217,510 A.2d at 1173 (Stein, J., dissenting).

118. See supra note 105 and accompanying text. 
ing business. ${ }^{119}$ When a manufacturer discovers a defect in a product, it normally has an incentive to remove the defect in order to lessen its exposure to potential liability. ${ }^{120}$ If a manufacturer must go through an extensive campaign to cure defective machines, and is met by an uncooperative einployer, it may become more cost efficient to retain the risk of hability than to continue to try to convince the employer of the wisdom of installing the curative device. ${ }^{121}$ This is especially true when the employer has no external incentive to cooperate. Thus, under the present system, needless accidents occur, and the public pays for them in both mcreased prices and injured bodies.

From a social standpoint, therefore, a duty between employers and manufacturers is the desired solution. Imposing a duty on einployers creates an imcentive for employers to weigh more carefully and reahistically the benefit of the curative device against the inconvemence of imstallation or the cost of reduced production. ${ }^{122}$ Manufacturers retain the motivation to be persistent $\mathrm{m}$ trying to cure because persistence may play an important role in later efforts to recover from einployers. ${ }^{123}$ The imposition of a duty to cooperate would result in a net reduction of imjury; fewer injuries mean less cost to the public.

b. Requiring independence and severability. If a duty is independent and severable from the duty employers owe to their employees, then it is outside the workers' coinpensation scheme, and damages for its breach are recoverable. ${ }^{124}$ Imposing a duty on employers to allow manufacturers to cure defects is consistent with both the independence and severability requirements. This duty, however, would not arise when an employer breaclies a duty to an employee and is concurrently neghgent with the manufacturer. ${ }^{125}$ In this case the duty is neither independent nor severable.

119. See supra note 38 and accompanying text.

120. Cf. Mitchell, supra note 12, at 375-76 (negatively implying that if corrective attempts would decrease liability, manufacturers normally would undertake them); Note, supra note 108, at 1646 (When the cost of accidents both in compensation and prevention is borne by one party, "that party's incentive to reduce its expenses will lead it to take cost-effective safety measures.").

121. Mitchell, supra note 12, at 375-76.

122. See supra note 120; $c f$. 2A A. LARSON, supra note 1, § 70.20, at 13-231, 13-232 (workers' compensation acts usually neglect objective of placing ultimate loss on actual wrongdoer, thereby losing deterrent effect); Mitchell, supra note 12, at 383 (neither safety statutes nor workers' compensation result in deterrence of wrongful conduct which is essential purpose of tort hability system).

123. Stephenson, 103 N.J. at 216-18, 510 A.2d at 1172-73 (Stein, J., dissenting) (whether manufacturer persistently frustrated in efforts to cure and whether employer thus breached independent duty to manufacturer would be determined by jury).

124. See supra notes 68,86 and accompanying text.

125. For examples of concurrent employer/manufacturer negligence, see cases cited supra note 12. 
An employer owes no duty to a manufacturer to use the manufacturer's product safely. For example, if a machine is found to be unreasonably dangerous when a safety guard is removed, an employer's act of removing the guard is the very danger that causes its unreasonably dangerous condition. ${ }^{126}$ The legal question is whether the manufacturer, when designing the machine, should have foreseen that the guard would be removed. In this situation, the manufacturer retains hability consistent with the goal of products hability, which is to induce manufacturers to desigu their products to be as safe as possible. ${ }^{127}$ The employer's actions are part of the use or misuse of the machine, and the employer owes a duty to the employee, not the manufacturer, to use the machine in a safe manner. ${ }^{128}$

When a manufacturer: has tried to the best of its ability to create a safe machine, that manufacturer has acted consistently with the purpose of products liability. If a defect is nonetheless discovered after the machine is placed in the market, the manufacturer incurs a duty to cure the defect, and will remain responsible for any resultimg imjury regardless of its original good-faith efforts. ${ }^{129}$ Any attempt by the manufacturer to cure a defect is therefore an attempt to remove already-existing potential liability. By persistently frustrating the manufacturer's attempts, an employer prevents the manufacturer from removing the dormant hability. Unlike the example of removing a guard, the employer's actions are not a manifestation of the potential hability; rather they prevent a separate, already-existing liability from being extmguished. This distinction is significant. When a manufacturer tries to cure a defect, ${ }^{130}$ an employer's refusal is not part of what makes the manufacturer originally hable but rather creates a second and separate issue. ${ }^{131}$ Thus, the duty mvolves

126. See infra note 132 and accompanying text.

127. See Stephenson, 103 N.J. at 216,510 A.2d at 1172 (Stein, J., dissenting) (products liability decisions encourage the optimuin investment in safety); see supra note 120 and accompanying text.

128. See supra note 104 and accompanying text. Likewise, the employer is under no obligation to cure a defect limself. Mitchell notes:

To ask a purchaser to install a device that a manufacturer in lis superior design experience thinks unnecessary is to ask that purcliaser to spend money on an item of dubious value. It is only when the manufacturer has taken all reasonable steps to convince tlie purchaser of the necessity for installing the device tluat a shift in responsibility should even be considered.

Mitchell, supra note 12, at 375; see Dorsey v. Yoder Co., 331 F. Supp. 753, 761-62 (E.D. Pa. 1971) (employer had no statutory duty to install guard and manufacturer had no reason to expect einployer to do so); $c f$. Lelın v. Clearview Dodge Sales, Inc., 400 So. 2d 317, 321-22 (La. Ct. App.) (manufacturer of motor home not intitled to indemnification froin dealer because dealer failed to notify manufacturer or remedy defects), cert. denied, 406 So. 2d 608 (La. 1981).

129. See supra notes 10-11 and accompanying text.

130. For instance, by offering to weld on guards that were previously screwed on.

131. As further illnstration, suppose an employer is warned of the danger of removing a safety guard and is asked to allow the manufacturer to weld the guard to the machine. The employer 
only the interactions of employers and manufacturers.

Because the law imposes a duty on manufacturers to correct the dangerous condition of a machine, manufacturers should have the right to discharge this duty. ${ }^{132}$ In blocking curative steps, employers infringe on this right and should have to answer for this infringement. Thus, an employer's interference can be conceived as the breach of a duty owed to a manufacturer - a duty that exists regardless of employee injury. Equity should permit a manufacturer to obtain a court order to force a recalcitrant einployer to allow the manufacturer to install a needed safety device before an imjury occurs. The duty to allow manufacturers to take curative steps involves only minimal cooperation with manufacturers and has nothing to do with employers' duties to their employees.

c. The fault requirement and judicial recognition of the special relationship. Although recognition of a special relationship between an einployer and a manufacturer is strongly supported by policy and equity, no court has yet recognized its existence. ${ }^{133}$ This hesitancy exists for two reasons. First, many courts have confused the idea of indemnity arising froin a special relationship with the idea of indemnity based on vicarious liability or passive negligence. Thus, these courts hold that indemnification based on a special relationship between a inanufacturer and an einployer can exist only if the inanufacturer-the indemnitee-is hable without personal fault. ${ }^{134}$ Because a manufacturer's hability is considered active, a inanufacturer is always at fault to some degree. Therefore, in the view of these courts, a manufacturer can never be in a special

refuses because the guard is awkward and he wishes to retain the ability to remove it. Subsequently, the employer does remove the guard and an employee is injured. The employer's act of removing the guard breached a duty owed to the employee to provide a safe workplace. His earlier action of refusing curative measures by the manufacturer breached a duty owed to the manufacturer to allow the defect to be corrected.

132. On the other hand, manufacturers should be denied the ability to shift responsibility to employers when they make no effort to provide safety devices or emphasize the need for them. "The very action upon which the manufacturer bases his request for a release from liability is a foreseeable consequence of the manufacturer's original failure to make available such a device." Mitchell, supra note 12, at 375 (emphasis added).

133. Mitchell, supra note 12 , at 384 .

134. Bullock v. Black \& Decker, Inc., 502 F. Supp. 580, 583 (E.D. Mich. 1980); Houdaille Indus., Inc. v. Edwards, 374 So. 2d 490, 493 (Fla. 1979); Decker v. Black \& Decker Mfg. Co., 389 Mass. 35, 40, 449 N.E.2d 641, 644-45 (1983); Kirin v. Riise Eng'g Co., 148 Mich. App. 278, 282, 384 N.W.2d 149, 151 (1986) (quoting Home Ins. Co. v. Jones \& Lamson, 144 Mich. App. 91, 97, 373 N.W.2d 249, 252 (1985), vacated, 424 Mich. 890, 381 N.W.2d 729 (1986)); Stephenson v. R.A. Jones \& Co., 103 N.J. 194, 200, 510 A.2d 1161, 1164 (1986); Sydenstricker v. Unipunch Prods., Inc., 169 W. Va. $440,445-46,288$ S.E.2d 511, 515 (1982). 
relationship vis-à-vis another culpable party. ${ }^{135}$ Second, courts appear hesitant to enforce a relationship that has not been traditionally recognized. Some courts fear that such an exception to the exclusive-remedy provision would be merely a judicial contrivance to circumvent the exclusive-remedy provision of workers' compensation. ${ }^{136}$ This reluctance seems to stem from "an unwillingness to tamper with what courts see as the fixed terms of the carefully designed legislative bargam underlying workers' compensation." 137 Neither of these reasons, however, prohibit recognizing a special relationship between a manufacturer and an employer.

A special legal relationship may be imphed without requiring that the one seeking indemnity be totally free from fault. ${ }^{138}$ When discussing the right to indemmity, several courts have correctly treated the disparity of fault requirement and the existence of a special legal relationship as separate inquiries. These courts recognize that the potential theories of recovery are not interdependent. ${ }^{139}$ Those courts requiring both factors misunderstand the development of indemnity and the circumstances under which it will be imposed. ${ }^{140}$ As Professor Keeton stated in The Law of Torts, "the principle [of indemnity] is not . . limited to those

135. See supra notes 70-81 and accompanying text; see also, e.g., Grayson v. Chambersburg Eng'g Co., 139 Mich. App. 456, 462, 362 N.W.2d 751, 754-55 (1984) (no indemnification under theory of implied agreement to negligent party).

136. See, e.g., Stephenson, 103 N.J. at 199, 510 A.2d at 1163.

137. Note, supra note 108 , at 1654 .

138. Stephenson, 103 N.J. at 208-09, 510 A.2d at 1168 (Stein, J., dissenting); $c f$. Dole v. Dow Chem. Co., 30 N.Y.2d 143, 150, 282 N.E.2d 288, 293, 331 N.Y.S.2d 382, 388 (1972) (indemnity can apply when one party less culpable than another although both liable to person injured).

139. Zapico v. Bucyrus-Erie Co., 579 F.2d 714, 718-19 (2d Cir. 1978) (indemnity available when one tortfeasor actively and the other passively neghigent, or where special relationship exists between parties); Hysell v. Iowa Pub. Serv. Co., 534 F.2d 775, 782 (8th Cir. 1976) (indemmity allowed if breach of independent duty or if vicarious or passive negligence of third party compared to active negligence of employer); Santistevelı v. Dow Chem. Co., 506 F.2d 1216, 1219 (9th Cir. 1974) (In absence of special legal relationship or indemnity contract, liability is shifted only when it is more just to shift the burden-when the indemnitor is more at fault.); Ranta v. Bethlehem Steel Corp., 287 F. Supp. 111, 112-13 (D. Conn. 1968) (indeinnity available when one tortfeasor actively and the other passively negligent, or where speeial relationship exists between parties); Burgdorff v. International Business Machs., 35 Inl. App. 3d 192, 194, 341 N.E.2d 122, 124-25 (1975) (to invoke implied indemnity must show either preexisting relationship or qualitative difference between negligence of two parties); Iowa Power \& Light Co. v. Abild Constr. Co., 259 Iowa 314, 322-23, 144 N.W.2d 303, 308-09 (1966) (indemnity permitted when right arises out of separate duty due third party from employer); Olch v. Pacific Press \& Shear Co., 19 Wash. App. 89, 93, 573 P.2d 1355, 1357 (1978) ("Indemnity may be permitted on the basis of an express contract, by virtue of vicarious liability, because of a breach of an independent duty between the indemnitor and the indemnitee, and because of the primary or 'active' tortious conduct of an indemnitor as compared to the secondary or 'passive' tortious conduct of the indemuitee.").

140. Stephenson, 103 N.J. at 200,510 A.2d at 1170 (Stein, J., dissenting). The majority of courts have required that inanufacturers must be wholly without fault. See, e.g., Houdaille Indus., Inc. v. Edwards, 374 So. 2d 490, 492-93 (Fla. 1979); Ramos v. Browning Ferris Indus., 103 N.J. 177, 188- 
who are personally free froin fault."141 A finding that a manufacturer is liable under a theory of products liability should not prevent courts from recognizing a special relationship carrying witlı it the obhgation to indemnify.

In addition, courts should not hesitate to enforce a legal duty between a inanufacturer and an employer simply because it is a new relationship that lacks precedent. ${ }^{142}$ All special legal relationships can be traced back to soine pohicy decision. ${ }^{143}$ Tort principles have always been broad and expansive, responding to new situations and developinents in society. ${ }^{144}$ Because of changes in the law after workers' coinpensation was enacted, courts can and should consider the exclusive-remedy rule in light of modern circuinstances and recognize exceptions when applicable. ${ }^{145}$ In hight of the general statutory scheme promoting safety in the workplace and the important public policy behind this scheme, courts should recognize tliose exceptions that do not subvert workers' coinpensation and that advance the desired goal of a safe workplace.

\section{CONCLUSION}

A literal application of the workers' compensation exclusive-reinedy provision extends that provision beyond its intended use-controlling the recoveries and habilities between employers and einployees. In those states where inplied indemnity claims are recognized, failure to include a special legal relationship between the inanufacturer and the employer has created an unauthorized safe harbor for employers and eliminates potentially vahid clains by third parties, such as those of a inanufacturer frus-

91, 510 A.2d 1152, 1158-59 (1986); Sydenstricker v. Unipunch Prods., Inc., 169 W. Va. 440, 445-47, 288 S.E.2d 511, 515-16 (1982).

141. Prosser \& KeEton, supra note $15, \S 51$, at 342; see also 2 A A. LARSON, supra note 1 , $\S 76.72$ (right of indenınity nıay still exist when fault of indemnitee is relatively minor). Professor Larson also implicitly recognizes that sonie circumstances exist in which the fault of the third party is not nerely constructive. He states that cases recognizing an independent relationship between the parties usually involve the constructive or imputed negligence of one party with the genuine negligence of the other party. He does not, however, suggest that imputed negligence is an absolute requirement. Larson, supra note 52, at 506.

142. Mitchell, supra note 12 , at 384, 395-96.

143. See, e.g., Prosser \& KeEtoN, supra note $15, \S 70$, at 500 (Vicarious liability is a "rule of policy, a deliberate allocation of a risk"); id. $\S 75$, at 536-37 (Strict liability may be imposed by asking, in view of the exigencies of social justice, who can best bear the loss.). These forms of liability are the ones that most often create special legal relationships, i.e., principal held vicariously liable for agent, bailor held strictly liable for injury caused by product (in control of bailee), lessor liable for injuries caused by property defects even when landlord promises to repair (even though property in lessee's control), nuanufacturer held strictly hable for failure to cure (even though product is in employer's control).

144. See, e.g., Note, supra note 108 , at 1645.

145. Id. at 1653-60. 
trated in attempts to cure. Noncontractual implied indemnity slould exist when an employer refuses to allow a manufacturer to cure defective products.

When faced witl an uncooperative employer, courts sliould look at the entire legislative scheme concerning tlie workplace and conclude that an independent duty exists between manufacturers and employers to allow inanufacturers to cure defective products. It is doubtful that legislatures ever meant employer immunization to cover tlose situations wlien an einployer, due to self-interest or disregard for tlie safety of employees, actually prevents a manufacturer from discharging the duty imposed by products liability to correct safety defects. ${ }^{146}$ Surely the legislature did not intend that a legal duty imposed on one party could be obstructed by the conduct of another party witlout repercussion.

Employers owe manufacturers an independent duty to cooperate minimally in curing defective maclimes, regardless of whether an employee is injured. In the case of litigation, the question of whether an employer frustrated the attempt to cure and the question of a manufacturer's good-faitl and reasonable attempt to cure slould be submitted to the jury to determine whether the independent duty has been breached. If such a breach has occurred, a manufacturer should be able to claim indemnity. This duty arises ouly when a manufacturer has taken affirmative action to correct defects and ouly imposes on an employer the obligation to allow the corrective measures.

Recognizing a special legal relationship between a manufacturer and an employer promotes the public interest in a safe workplace and maximizes efforts toward achieving safety. Manufacturers will still attempt,

146. For example, the Supreme Court found the legislative history of the Federal Employee Compensation Act to reveal Congress's intent in enacting the exclusive-remedy provision:

"The purpose ... is to make it clear that the right to compensation benefits under the act is exclusive and in plaee of any and all other legal liability of the United States ....

"Workmen's Compensation laws, in general, specify that the remedy therein provided shall be the exclusive remedy. 'The basic theory supporting all workmen's compensation legislation is that the remedy afiorded is a substitute for the employee's (or dependent's) former remedy at law for damages against the employer. ... The inadequacy of the benefits under the Employees' Compensation Act has tended to cause Federal employees to seek relief under these general statutes. ...

"This situation has been of considerable concern to all Government agencies and especially to the corporate instrumentalities. Since the proposed remedy would afford employees and their dependents a planned and substantial protection, to permit other remedies by civil action or suits would not only be unnecessary, but would in general be uneconomical, from the standpoint of both the beneficiaries involved and the Government."

Weyerhaeuser S.S. Co. v. United States, 372 U.S. 597, 601 n.5 (1963) (quoting S. REP. No. 836, 81st Cong., 1st Sess. 23 (1949) (emphasis added)).

The Supreme Court interpreted this legislative history to indicate that in enacting the Compensation Act, Congress was not concerned with the "rights of unrelated third parties, much less of any purpose to disturb settled doctrines of .. . law affecting [their] mutual rights and liabilities." Id. at 601. 
m the first imstance, to make machines as safe as possible because this relationship does not reheve them from any liability for undiscovered defects. When and if a defect is subsequently discovered, a manufacturer would be held to a standard of reasonableness and good-faith im any attempts to cure; the manufacturer must take affirmative action and that action must be refused before its hability will be excused. This standard provides the needed imcentive both to correct the defect and to make sure that safety devices are installed. An employer is faced with the threat of a large damage verdict if she refuses the manufacturer's devices or refuses to allow them to be mstalled by the manufacturer. The duty to cooperate consists simply of not preventing the manufacturer from carrying out certain obhgations. Employees will benefit from fewer injuries and a safer working environment. In the event injury does occur, an employee preserves all rights and privileges.

The principles of indemnity and the idea of duty are flexible enough to allow the recognition of a special relationship between a manufacturer and an employer in this limited situation. By imposing a special relationship, courts will be able to administer the law in a fair and just manner, and at the same time, uphold the legislative intent behind workers' compensation. Courts should feel obligated to protect a manufacturer's right to discharge a duty imposed on it by law. Protectimg this right will, in the long run, protect workers as well as the society that orginally imposed the duty. 